\title{
The Role of the Junior College Library in Connection with Terminal Education
}

\section{INTRODUCTION}

\author{
By Wave L. Noggle, librarian, Virginia (Minn.) Junior College Library \\ and chairman of the Junior College Libraries Section, A.C.R.L.
}

The contribution of the junior college library in helping to win the war is directly dependent upon that which the junior college undertakes. Perhaps the greatest wartime adjustment in most junior colleges has been the addition of certain terminal courses. Thus, instead of papers on such a subject as "what the junior college library is doing to help win the war," the broader subject of terminal courses has been chosen for this symposium. This subject, of course, covers the work done with all terminal courses and, hence, includes an important phase of library work in connection with helping to win the war.

Each of the following papers is presented from a distinct point of view-that of a library in : 1 . a large public coeducational junior college, 2. a large private junior college for girls, and 3. a small private junior college for men. It is believed that the three viewpoints as presented give a good picture of the work done in junior college libraries in connection with terminal courses.

\section{Terminal Education and the Library at Woodrow Wilson Junior College}

Mr. Hughes is librarian, Woodrow Wilson Junior College, Chicago.

$\mathrm{W}$ OOdRow Wilson Junior College is a large public coeducational junior college, one of three operated by the Chicago Board of Education. It is a day school, with no night or extension classes. The present enrolment is 1347 . The college library is perhaps unique, in that it serves Chicago Teachers' College also, the latter a four-year, degree-granting 
institution, which was a going concern as Cook County Normal School before any junior colleges came into being. Wilson Junior thus came into partial possession of an already functioning library when it was founded in 1934 .

There seems to be a general feeling here that the work of the junior college does not differ fundamentally, for a majority of students, from the first two years of any liberal arts college. That it serves as a jumping-off place, rather than an end, is indicated by the fact that almost 80 per cent of the students apply for transcripts, presumably to admit them elsewhere, to continue their formal education. For students who expect to complete their formal education in the junior college, two types of terminal work are offered: a terminal general program, "primarily cultural and indirectly vocational;" and a terminal vocational program "for students who prefer definite occupational training." It is only the latter which differs markedly from the typical "arts" curriculum.

\section{Curricula}

There are ten curricula of this vocational type; seven two-year and three oneyear. The two-year are: accounting and general business, merchandising, secretarial, medical or dental secretaries, technicians in chemistry, technicians in engineering (general and drafting), and aviation and transportation. The oneyear are: accounting and general business, secretarial, and technical. These oneyear curricula represent a concession to the wartime needs of students and the work for which they are training. All the general surveys, which are the most distinctive feature of the municipal junior colleges' program, are omitted, and the student is not certified for advanced study elsewhere of course. Another special program is that in defense activities, for which all students are required to register for one hour's work per week. Thirtythree activities are offered under the general headings: technical, business, health, recreational and informational, and service. For a fuller discussion of this program, see the article, "Defense Activities at Woodrow Wilson" by Beulah Berolzheimer, special assistant to the dean, in the Junior College Journal, September 1942. Another effect of the war is seen in increased enrolment in certain courses, such as engineering drawing and materials, mathematics, chemistry, and physics, and in the establishment of new courses, such as navigation. Actual increases in above courses were $60,4 \mathrm{I}, 49$, and 77 , respectively, in spite of a $\mathrm{I} 7$ per cent decrease in the total college enrolment.

What changes in library service have been necessary as a result of these new activities and changes of emphasis in the old? The answer is, very little, and the reason becomes clear after consideration of the whole situation. In the first place, the gross enrolment in the survey courses, including duplications, is still 72 per cent of the college enrolment, just as it was last year, and the decrease in English and social sciences is slight. The courses, then, which use the library most have suffered little or not at all. On the other hand, the courses which have grown are those which depend on the textbook, the laboratory, and the workroom rather than the library. Specifically, students of ballistics, radio code, business machines, and the like, will find the library distinctly supplementary, if, indeed, they use it at all.

For the terminal general program, then, 
the library's role is not much different from that for the first two years of the teachers' college; it is chiefly to furnish required readings in as adequate a number of copies as possible. For the terminal vocational program, the library does little more than furnish collateral reading for the occasional student who wants to go beyond his text or who wants background for his laboratory work. Only in a few special cases have we done more. For work in cooperative retailing, the reference department has serviced pamphlet materials gathered by the instructor, keeping them in the vertical file and in pamphlet boxes and handling them much like other pamphlets. Guidance material, particularly that issued by the Science Research Associates, has been treated in the same way, in cooperation with the department of counseling.
The library tries to help the faculty bring home to all students, terminal and other, the nature of the war, the United Nations idea, and the importance of unity behind the war effort within our own country. This has been done for the most part by purchasing increasing numbers of books along these lines and making available the periodicals which deal particularly with the war and postwar problems. This reading program has not developed to our satisfaction yet and is a challenge to the faculty and to the library. Perhaps students get a better understanding of the spirit animating the United Nations from participation in defense activities of various kinds than they do from reading about the war and the peace. We hope the library is at least a factor in understanding and unity and, therefore, in bringing victory and a lasting peace.

\section{The Junior College Library and Terminal Education}

Mr. Johnson is librarian and dean of instruction. Stephens College, and Miss Johns is librarian and research associate, Institute for Consumer Education Library, Stephens College.

$\mathrm{T}$ HE ROLE of the junior college library in terminal education is identical with its role in any other aspect of the educational program. In other words, the function of the library (in terminal education, in preparatory education, in professional education) is to cooperate with teachers and students in developing and carrying out the most effective methods of using library materials as an aid to attaining course objectives and-even more important-the objectives of individual students. More specifically, as the writers see the problem, the library must: 